\title{
Relationship between Profile Characteristics of Farmers and their Perception about Suitability of Extension Teaching Methods in Telangana State, India
}

\author{
P. Nikitha*, V. Sudha Rani, G. Samuel and A. Madhavilata
}

Department of Agricultural Extension, College of Agriculture, Professor Jayashankar Telangana State Agricultural University, Rajendranagar, Hyderabad - 500030, Telangana, India

*Corresponding author

A B S T R A C T

The research study was carried out to know relationship between profile characteristics and perception of farmers about suitability of extension teaching methods in Telangana state. The data were collected from 120 respondents randomly representing 12 villages of

Keywords

Relationship, Profile, Farmers, Extension teaching methods

Article Info

Accepted:

16 August 2018

Available Online:

10 September 2018 two districts namely Nalgonda and Mahaboobnagar districts of Telangana state during the year 2016-17 using structured interview schedule. The findings revealed that the less than majority 41.66 percent of the respondents had very low level of perception about suitability of extension teaching methods, followed by low, medium, high and very high level of perception about suitability of extension teaching methods. This paper throws the light on the profile characteristics of the farmers and perception. Findings revealed that the independent variables viz. training received, innovativeness and access to learning resources exhibited positive and significant relationship at five per cent level of significance whereas age, education, mass media exposure, socio-political participation and use of extension teaching methods by extension personnel at one per cent level of significance. Farm size, farming experience, farm income, possession of communication tools, participation in extension activities and traditionalism exhibited non-significant relationship with perception about suitability of extension teaching methods by the farmers.

\section{Introduction}

Outreach and Extension services play an important role in enhancement of farmers' skills (innate and learned) as well as their ability of processing information for their effective learning, help farmers make better decisions and consequently improve their welfare (Wozniak, 1987; Anderson and Feder, 2003). The link between research sources and farmers is strengthened by Extension services because Extension agents transfer innovations to farmers by deploying several extension teaching methods. According to Anderson and Feder (2003), the impact expected by Outreach and Extension programs may be affected by both actors: 1) farmers and their profile characteristics which affect the way farmers operate and accept innovations based on their perceptions and 2) Extension agents 
and the way they deliver information to farmers by using suitable extension teaching methods. Therefore, a clear understanding on perception of farmers towards extension teaching methods has been primarily focused because farmers' demographics and technologies are constantly changing.

\section{Materials and Methods}

The study was conducted in Mahaboobnagar and Nalgonda districts of Telangana state during 2016-17. An Ex-post-facto research design was employedin the present investigation. Hundred and twenty farmers were selected through random sampling method from Mahaboobnagar and Nalgonda districts of Telangana state as respondents. Perception was operationalized in the study as the ability to perceive the suitability of different extension teaching methods by the farmer.

Statements related to Extension teaching method wise under Individual, group and mass contacts this variable is measured using three point continuum viz., Agree, Undecided and Disagree. The scoring was given as 3, 2 and 1 respectively. The total score was obtained by summing up all the items and respondents were classified in to 5 categories based on exclusive class interval technique. The data was coded, classified and tabulated and subjected to frequencies and percentages to meaningfully interpret the findings. Profile characteristics of the farmers like Age, Education, Farm size, Farming experience, Farm income, Training received, Innovativeness, mass media exposure, Possession of communication tools, Participation in extension activities, Access to Learning resources, Traditionalism, Sociopolitical participation and Use of extension teaching methods by extension personnel were correlated with the farmers perception about suitability of extension teaching methods to know the significant and non-significant relationship between the variables.

\section{Results and Discussion}

The findings are regarding perception of farmers about suitability of extension teaching methods. It was evident from the Table 1 indicate that majority $(41.66 \%)$ of the respondents fall under very low level of perception about suitability of extension teaching methods, followed by low (32.50\%), $(16.66 \%)$ medium, high $(6.66 \%)$ and $(2.5 \%)$ under very high level of perception about suitability of extension teaching methods. The above trend was due to the fact that that most of the respondents in the study area belonged to old age category with high farming experience think that they would know much better about their field situations than anyone else, different teaching methods used by the extension personnel may not be applicable to his farming situation, infrequent visits made by the extension personnel to the farmers fields.

Correlation analysis was employed to access the relationship between the perception of farmer about suitability of extension teaching methods and their profile characteristics. The correlation coefficients were worked out and the significance was tested by comparing with the table values. The results are represented in Table 2.

It was revealed from the Table 2 that the calculated ' $r$ ' values between age, education, mass media exposure, socio-political participation and use of extension teaching methods by extension personnel were greater than table ' $r$ ' value at 0.01 level of probability, whereas, the calculated ' $r$ ' values of variables training received, innovativeness and access to learning resources were greater than table ' $\mathrm{r}$ ' value at 0.05 level of probability. Hence, null hypothesis was rejected and empirical 
hypothesis was accepted. Therefore, it could be concluded that there was a positive and significant relationship between the perception of farmer about suitability of extension teaching methods and the variables age $\left(0.322^{* *}\right)$, education $\left(0.248^{* *}\right)$, training received $\left(0.204^{*}\right)$, mass media exposure $(0.242 * *)$, socio-political participation $\left(0.549^{* *}\right)$, use of extension teaching methods by extension personnel $\left(0.373^{* *}\right)$, innovativeness $\left(0.197^{*}\right)$ and access to learning resources $(0.234 *)$.

Table.1 Distribution of respondents based on their perception about suitability of extension teaching methods $(\mathrm{N}=120)$

\begin{tabular}{|l|l|c|c|c|}
\hline S. No & Category & Class Interval & Frequency & Percentage \\
\hline 1. & Very Low Level of perception & $205-220$ & 50 & 41.66 \\
\hline 2. & Low level of perception & $220-235$ & 39 & 32.50 \\
\hline 3. & Medium level of perception & $235-250$ & 20 & 16.66 \\
\hline 4. & High level of perception & $250-265$ & 8 & 6.66 \\
\hline 5. & Very high level of perception & $265-280$ & 3 & 2.5 \\
\hline
\end{tabular}

Table.2 Relationship between profile characteristics and perception of farmer about suitability of extension teaching methods

\begin{tabular}{|c|c|c|}
\hline S. NO. & Characteristics & Correlation coefficient (r) \\
\hline 1. & Age & $0.322 * *$ \\
\hline 2. & Education & $0.248^{* *}$ \\
\hline 3. & Farm size & $0.075 \mathrm{NS}$ \\
\hline 4. & Farming experience & $0.128 \mathrm{NS}$ \\
\hline 5. & Training received & $0.204^{*}$ \\
\hline 6. & Farm income & $0.039 \mathrm{NS}$ \\
\hline 7. & Innovativeness & $0.197^{*}$ \\
\hline 8. & Possession of communication tools & $0.170 \mathrm{NS}$ \\
\hline 9. & Participation in extension activities & $0.123 \mathrm{NS}$ \\
\hline 10. & Mass media exposure & $0.242 * *$ \\
\hline 11. & Access to Learning resources & $0.234^{*}$ \\
\hline 12. & Traditionalism & $0.056 \mathrm{NS}$ \\
\hline 13. & Socio-political participation & $0.549^{* *}$ \\
\hline 14. & $\begin{array}{l}\text { Use of extension teaching methods by } \\
\text { extension personnel }\end{array}$ & $0.373^{* *}$ \\
\hline
\end{tabular}

On the other hand calculated ' $r$ ' values between farm size $(0.075 \mathrm{NS})$, farming experience $(0.128 \mathrm{NS})$, farm income (0.039NS), possession of communication tools $(0.170 \mathrm{NS})$, participation in extension activities (0.123NS) and traditionalism $(0.056 \mathrm{NS})$ were less than table ' $r$ ' value. Hence, null hypothesis was accepted and empirical hypothesis was rejected. Therefore, it could be concluded that there was no 
significant relationship between perception of farmer about suitability of extension teaching methods and the variables farm size, farming experience, farm income, possession of communication tools, participation in extension activities and traditionalism.

It can be observed that most of the farmers were old age group they might have acquired better understanding of the technologies and might got familiar with the extension teaching methods being used by extension personnel, increase in education levels of the farmer they will be more aware regarding importance of different extension teaching methods suitable to his farming situation resulted in making rational, quicker decisions that would help in adoption of innovations, medium to high level of training received by the farmers resulted in favourable perception of farmers about suitability of extension teaching methods, high participation in training programmes, most of the farmers had good contact with the extension personnel which made them to try new things in advance compare to other farmers resulting in high innovativeness, by exposure to different mass media sources not only literate farmers but also illiterate farmers can get access to information resulting in positive perception with that of the extension teaching methods, active participation in social and political organizations and community activities they could get benefits where the extension worker provides awareness to the farmers for convincing them to participate by using suitable extension teaching methods, high usage of extension teaching methods by the extension personnel suitable to the farmer were the reasons that resulted in positive and significant relationship between these profile characteristics and perception of farmer about suitability of extension teaching methods. The extension teaching methods used by extension officers would cover all farmers with different farm holdings, even though the farmer possess different communication tools he may not perceive them to be suitable to use for getting farm situation, Simply by participation in extension activities may not result in effective learning, generally people believe in more traditional aspects, rituals and traditions may not have favourable perception towards modern extension teaching methods were the problems posed a negative impact on perception of the extension teaching methods.

Generally the small and marginal farmers in the village are mostly unreached by the extension system. Hence the extension system should concentrate on small and marginal farmers, the importance of active participation in training programmes should be made aware to the farmers, farming experiences should be shared among farmers using discovery based learning methods, Extension programs have to be designed to: 1) provide desired experiential opportunities for the learner, 2) reinforce the learner, and 3) provide opportunities for the learner to integrate new information with existing knowledge and skills if the farmers were benefited financially by attending the extension activity or method definitely he will develop positive attitude towards that activity or method, deploying suitable extension teaching methods relevant to the farmers learning styles should be focused to develop favourable and positive perception of farmers towards suitability of extension teaching methods.

\section{References}

Ayesha Khan and Muhammad Akram. 2012. Farmers perception on extension teaching methods by extension personnel for dissemination of new agricultural technologies in Khyber Pakhtunkhwa, Pakisthan, Department of Agricultural Extension Education \& Communication, Agricultural University, Peshawar-Pakistan. 28(3). 
Buch, K., and Bartley, S. 2002. Learning Style and Training Delivery Mode Preference. Journal of Workplace Learning. 14(1): 5-10.

Feder, A., 2003. Extension teaching methods of farmers, Journal of educational and Instructional studiesin the world. 2(3): 2146-7463.
Franz, N. K., Piercy, F., Donaldson, J., Westbrook, J and Richard, R. 2010. Farmer, agent, and specialist perspectives on preferences for learning among today's farmers. Journal of Extension. June. 48(3).

\section{How to cite this article:}

Nikitha, P., V. Sudha Rani, G. Samuel and Madhavilata, A. 2018. Relationship between Profile Characteristics of Farmers and Their Perception about Suitability of Extension Teaching Methods in Telangana State, India. Int.J.Curr.Microbiol.App.Sci. 7(09): 2298-2302. doi: https://doi.org/10.20546/ijcmas.2018.709.284 